УДК 634.1:631.52

DOI 10.30679/2219-5335-2019-4-58-1-10

ОЦЕНКА КРУПНОПЛОДНОСТИ СОРТОВ ЯБЛОНИ

В УСЛОВИЯХ

ЮЖНОГО РЕГИОНА РОССИИ

Атабиев Кязим Мурадинович ${ }^{1}$

главный агроном-садовод

СПК «Де-Густо»

Ульяновская Елена Владимировна ${ }^{2}$

д-р с.-х. наук

зав. лабораторией сортоизучения

и селекции садовых культур

e-mail: ulyanovskaya_e@mail.ru

Засеева Роксана Муратовна ${ }^{1}$

специалист

СПК «Де-Густо»

Беленко Евгения Анатольевна ${ }^{2}$ младший научный сотрудник лаборатории сортоизучения и селекции садовых культур

${ }^{1}$ СПК «Де-Густо», с. Эльхотово, Северная Осетия-Алания, Россия

${ }^{2}$ Федеральное государственное бюджетное научное учреждение «Северо-Кавказский федеральный научный центр садоводства, виноградарства, виноделия», Краснодар, Россия

В статье дана оценка сортов яблони отечественной и зарубежной селекции в условиях Республика Северная Осетия-Алания по одному из важнейших признаков качества плодов крупноплодности. Исследования проводили согласно общепринятым и разработанными сотрудниками центра селекции ФГБНУ СКФНЦСВВ программам и методикам селекции и сортоизучения. Объекты исследований генотипы яблони разной плоидности и генетического происхождения. Всего в изучении было 25 сортов яблони, из них 13 отечественной и 12 зарубежной
UDC 634.1:631.52

DOI 10.30679/2219-5335-2019-4-58-1-10

\section{ASSESSMENT OF LARGE-FRUITED APPLE VARIETIES UNDER THE CONDITIONS OF SOUTHERN REGION OF RUSSIA}

Atabiev Kyazim Muradinovich ${ }^{1}$

Chief Agronomist-gardener

of APC «De-Gousto»

Ulyanovskaya Elena Vladimirovna ${ }^{2}$

Dr. Sci. Agr.

Head of Laboratory of Variety study and Breeding of Garden crops e-mail: ulyanovskaya_e@mail.ru

Zaseyeva Roksana Muratovna ${ }^{1}$ Specialist of APC «De-Gousto»

Belenko Evgenia Anatolyevna ${ }^{2}$ Junior Research Associate of Laboratory of Variety study and Breeding of Garden crops

${ }^{1} A P C$ «De-Gousto», v. Elkhotovo, Northern Ossetia-Alania, Russia

${ }^{2}$ Federal State Budget

Scientific Institution

"North Caucasian Federal

Scientific Center of Horticulture,

Viticulture, Wine-making»,

Krasnodar, Russia

The article assesses the apple varieties of domestic and foreign breeding in the Northern Ossetia-Alania using the one of the most important signs of fruit quality - large fruiting. The studies were carried out according to the programs and methods generally accepted and developed by the staff of the center for selection of FSBSI NCFSCHVW. The objects of research are apple genotypes of different ploidy and genetic origin. In total, there were 25 apple varieties in the study, of which 13 are domestic and 12 are foreign breeding. According 
селекции. По итогам многолетних исследований выделены наиболее крупноплодные в условиях южного региона России сорта и элитные формы яблони: летний сорт Союз, осенние Василиса, Кармен, Любава, Талисман, раннезимний Лигол, зимние и позднезимние - Любимое Дутовой, Золотая корона, 12/2-20-35, Прикубанское. Среди выделенных по ценному для селекции признаку крупноплодности все сорта яблони региональной селекции, за исключением сорта Лигол. Наиболее крупноплодный среди летних сортов Союз (330 г); среди всех остальных изученных сортов - Талисман, средняя и максимальная масса плодов которого 523,6 г и 534,0 г, соответственно. Большинство из выделенных по крупноплодности сортов и элитных форм яблони получены в результате совместной селекции ФГБНУ СКФНЦСВВ и ФГБНУ ВНИИСПК и имеют иммунитет к парше: Союз, Василиса, Кармен, Любава, Талисман и 12/2-20-35.

Изучение сортов и элитных форм яблони различного генетического происхождения, плоидности и разных сроков созревания в условиях Республика Северная ОсетияАлания позволило выделить наиболее ценные из них для использования в селекции и производстве.

Ключевые слова: ЯБЛОНЯ, СОРТ, ЭЛИТНАЯ ФОРМА, КРУПНОПЛОДНОСТЬ to the results of long-term studies, the most large-fruited varieties and elite forms of apple-tree were selected in the Southern region of Russia: the summer variety of Soyus, autumn Vasilisa, Carmen, Lyubava, Talisman, early winter - Ligol, winter and late winter - Lyubimoe Dutovoy, Zolotaya Krona, 12/2-20-35, Prikubanskoe. Among the varieties selected by valuable sign of large-fruited, there are all apple varieties of regional breeding, excepting the Ligol variety. The most large-fruited among summer varieties - Soyus variety (330 g); among all the studied varieties - Talisman, the average and maximum fruit weight of which is $523.6 \mathrm{~g}$ and $534.0 \mathrm{~g}$, respectively. The most of the cultivated varieties and elite forms of apple-tree selected for large-fruited sign were obtained as a result of the joint breeding of the FSBSI NCFSCHVW and the FSBSI All-RRIHB and they are immune to scab: Soyuz, Vasilisa, Carmen, Lyubava, Talisman and 12/2-20-35. The study of apple varieties and elite forms of different genetic origin and ploidy and different ripening terms in the conditions of Northern Ossetia-Alania allowed us to identify the most valuable of them for use in breeding and production.

Key words: APPLE-TREE, VARIETY, ELITE FORM, LARGE-FRUITED SIGN

Введение. В настоящее время одно из главных селекционных направлений по яблоне - совершенствование качества плодов, что обусловливает необходимость сбора, создания и изучения исходного материала, представленного лучшими в этом отношении сортами мировой и отечественной селекции [1-4]. Значительна роль экологического сортоиспытания в изучении мирового и отечественного, в том числе регионального сортимента [2, 3].

Признак крупноплодности - один из важнейших при исследовании показателей качества плодов яблони и выделении наиболее ценных для се- 
Плодоводство и виноградарство Юга России № 58(04), 2019 г.

лекции и производства генотипов. Использование метода полиплоидии зачастую значительно облегчает работу в этом селекционном направлении. В то же время наиболее приоритетная задача селекции яблони в мире - coвмещение наиболее высоких коммерческих характеристик качества плодов и устойчивости сорта к основным грибным патогенам [3, 5-15].

Генетическое разнообразие - основа ускоренного создания перспективных сортов яблони [16-18]. Поэтому важнейшей составляющей селекционных программ по яблоне являются источники адаптивности к абио- и биотическим стрессорам [1-4, 18-21]. Однако, нередко носители признаков высокой засухоустойчивости, зимостойкости, устойчивости к болезням, ценного биохимического состава - это мелкоплодные видовые и межвидовые формы, при использовании в селекции которых так важна крупноплодность выбранной второй исходной формы.

Цель исследований - выделить на основе многолетних исследований сорта яблони отечественной и зарубежной селекции - источники признака крупноплодности для использования в селекции и производстве.

Объекты и методы исследований. Объекты исследований - генотипы яблони (Malus x domestica Borkh.) разной плоидности и генетического происхождения. Большинство из созданных в СКФНЦСВВ иммунных и высокоустойчивых к парше сортов яблони получены в результате длительной совместной селекционной работы с ВНИИСПК (г. Орел). Исследовательская работа проведена в 2014-2017 гг. в полевых условиях (СПК «Де-Густо», РСО Алания) в садах яблони общей площадью 18,0 га; подвой ММ 106. Схема посадки 5х2.

В работе использованы селекционные программы и методики: «Программа Северо-Кавказского центра по селекции плодовых, ягодных, цветочно-декоративных культур и винограда на период до 2030 года» (2013) [4]; «Современные методологические аспекты организации селекционного процесса в садоводстве и виноградарстве» (2012) [3]; «Программа и мето- 
Плодоводство и виноградарство Юга России № 58(04), 2019 г.

дика сортоизучения плодовых, ягодных и орехоплодных культур» (1999) [2]; «Программа и методика селекции плодовых, ягодных и орехоплодных культур» (1995) и др. [1, 18-21].

Оценка качественных показателей плодов, в том числе по признаку крупноплодности, проводится для новых сортов и элитных форм, выделившихся при агробиологическом изучении [2]. Контролем служат плоды районированных для данной зоны сортов, выращенных в тех же агроклиматических условиях.

Обсужнение результатов. Для правильной оценки сорта отбор образцов имеет важное значение. Необходимо учитывать их расположение в кроне и отбирать плоды, развивающиеся из центральных цветков, так как они меньше подвержены влиянию окружающей среды и соответственно более полно отражают наследственные особенности сорта. Такие плоды имеют типичные для данного сорта размер, форму и окраску, более короткую и толстую плодоножку.

Плоды яблони необходимо отбираться в оптимальной степени зрелости, с разных сторон кроны по отношению к сторонам света, выбирая наиболее типичные по форме, окраске и степени зрелости плоды с 3-5 деревьев каждого сорта.

При изучении массы плодов сортов яблони в сравнении с контролем нами выявлено, что размах изменчивости средней массы плода у генотипов летнего срока созревания составляет от 130 г (сорт Рассвет) до 330 г (Союз); максимальной массы - от 160-165 г (Рассвет, Джерсимак) до 395 г (Союз) (рис. 1). Все летние сорта яблони, за исключением крупноплодного сорта Союз (селекции СКФНЦСВВ совместно с ВНИИСПК) уступают контрольному сорту Новелла по средней и максимальной массе плода. У сортов яблони осеннего и раннезимнего срока созревания размах изменчивости средней массы плода составляет от 140,0-144,9 г (Гала Галакси, Чемпион 
Рено) до 523,6 г (Талисман); максимальной массы плода - от 169,0-172,0 г (Гала Галакси, Чемпион Рено) до 530,4 г (Талисман) (рис. 2).

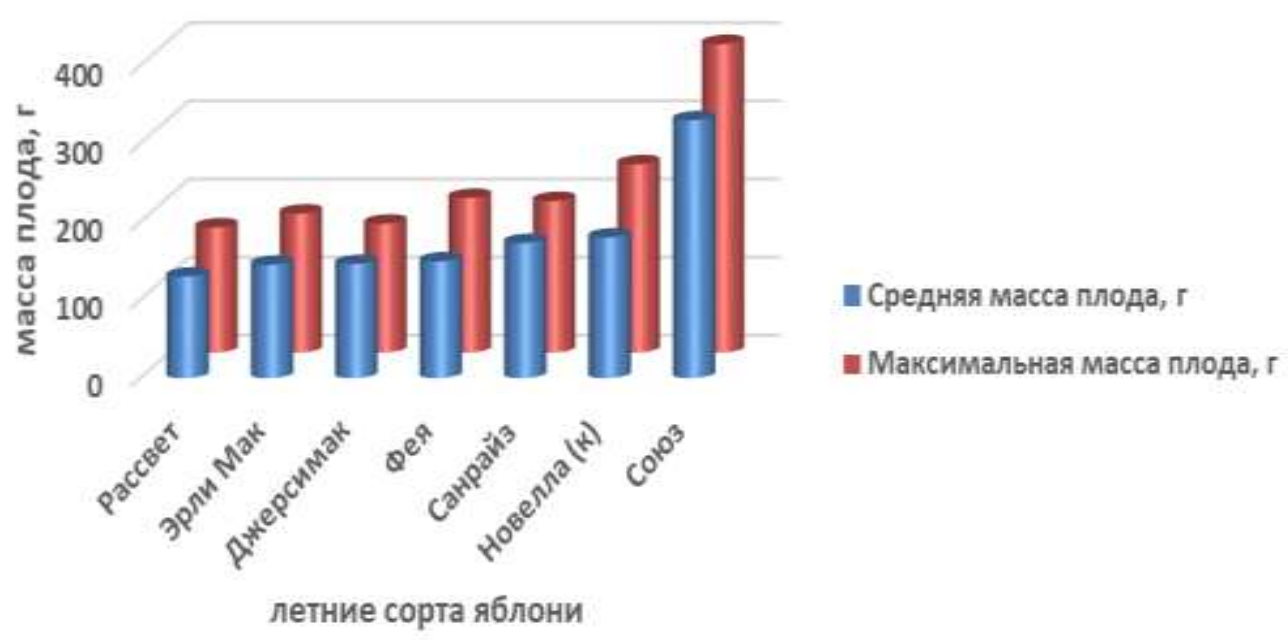

Рис. 1. Средняя и максимальная масса плода сортов яблони летнего срока созревания

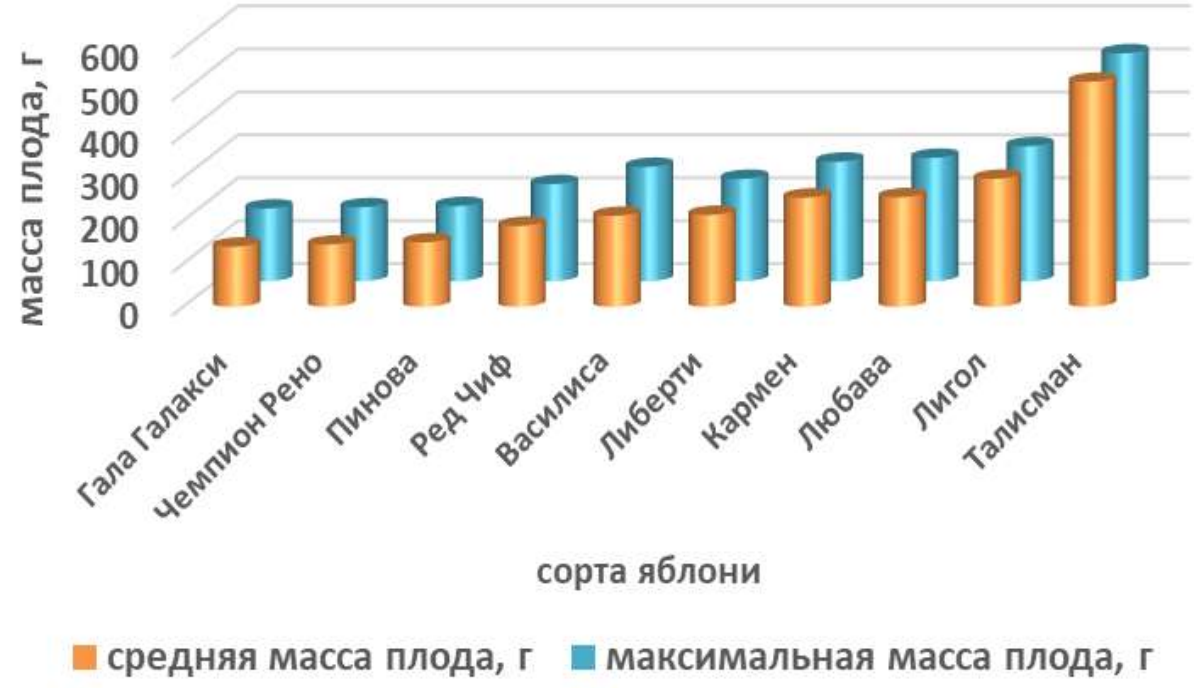

Рис. 2. Средняя и максимальная масса плода сортов яблони осеннего и раннезимнего срока созревания

По результатам многолетних исследований выделены крупноплодные сорта яблони Василиса, Кармен (рис. 3), Любава (рис. 4), Лигол, Талисман (рис. 5). Наиболее крупноплодный среди изученных нами сортов различных сроков созревания - Талисман. 
Плодоводство и виноградарство Юга России № 58(04), 2019 г.

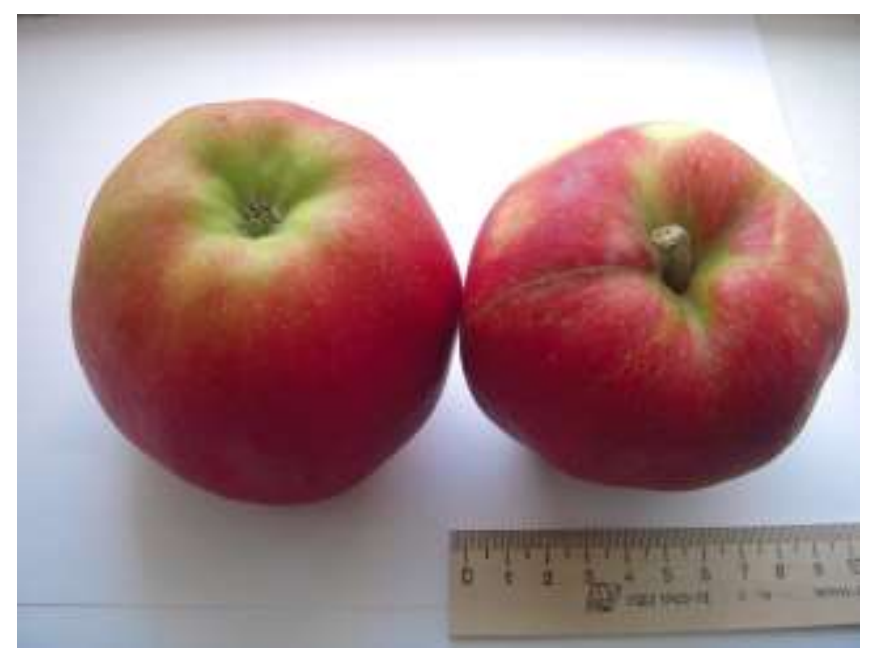

Рис. 3. Плоды сорта яблони Кармен

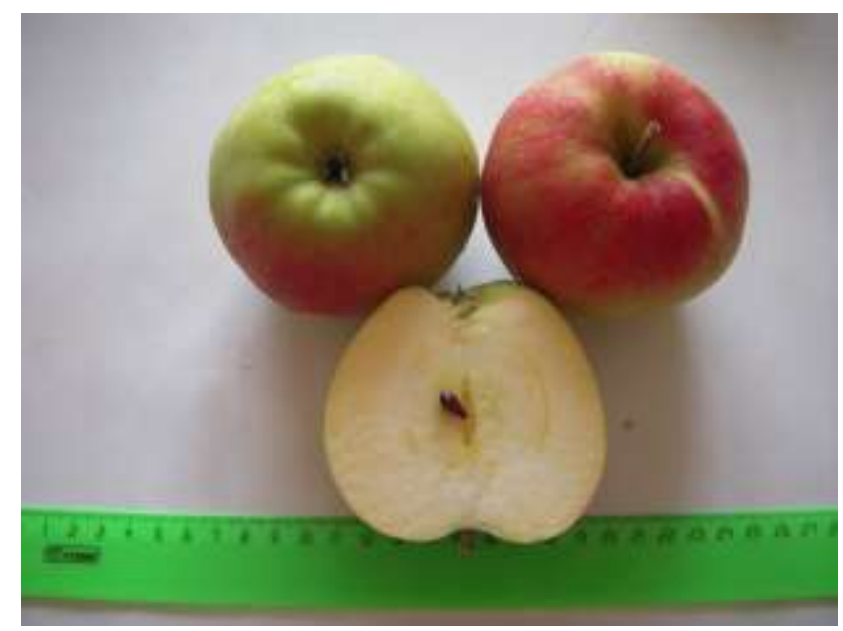

Рис. 4. Плоды сорта яблони Любава

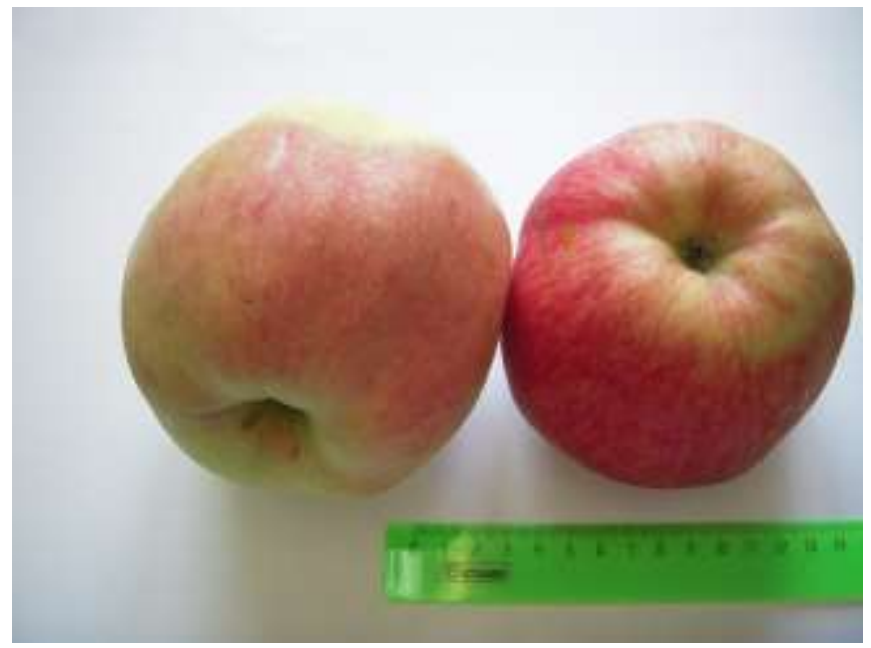

Рис. 5. Плоды сорта яблони Талисман 
Среди изученных генотипов яблони зимнего и позднезимнего срока созревания наиболее крупноплодны в условиях РСО-Алании сорта и элитные формы региональной селекции: Любимое Дутовой, Золотая корона, 12/2-20-35, Прикубанское (рис. 6).

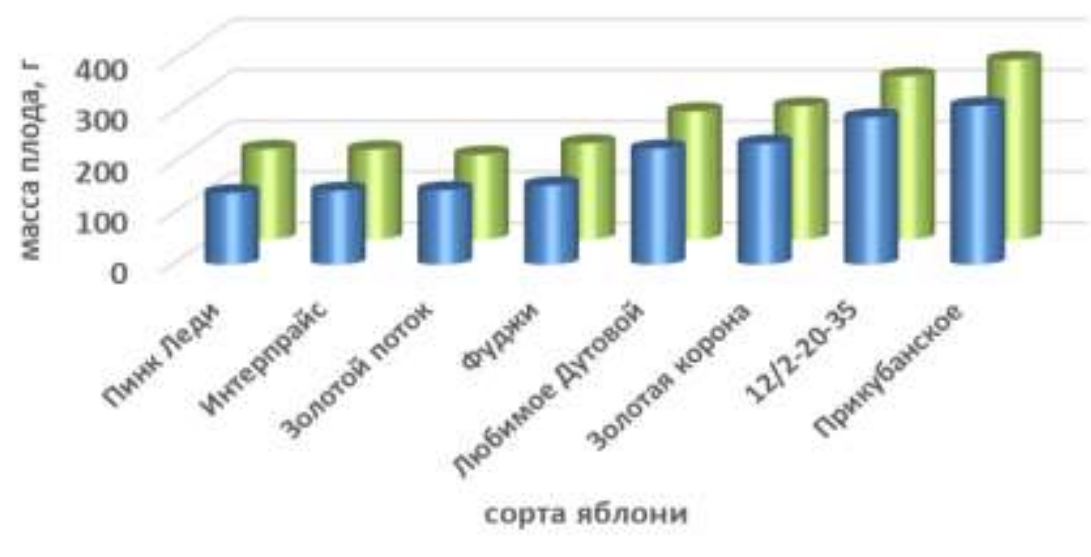

- средняя масса плода, $\mathrm{r}$ м максимальная масса плода, $\mathrm{r}$

Рис. 6. Средняя и максимальная масса плода сортов яблони зимнего и позднезимнего срока созревания

Размах изменчивости средней массы плода изученных сортов яблони составляет от 140,6-146,3 г (Пинк Леди, Интерпрайс, Золотой поток) до 312,0 г (Прикубанское); максимальной массы плода - от 167,0 г (Золотой поток) до 321,0-353,0 г (12/2-20-35, Прикубанское).

Необходимо отметить, что среди выделенных по важнейшему селекционному признаку крупноплодности все сорта яблони региональной селекции, за исключением сорта Лигол. Большинство из выделенных по крупноплодности сортов региональной селекции имеют иммунитет к парше. Это сорта: Союз, Василиса, Кармен, Любава, Талисман и элитная форма 12/2-20-35 селекции ФГБНУ СКФНЦСВВ совместно с ФГБНУ ВНИИСПК. Наиболее крупноплодный среди сортов летнего срока созревания - триплоидный сорт Союз. Среди всех изученных нами сортов наиболее крупноплодный - осенний сорт Талисман, обладающий средней и максимальной массой плодов более 500 г, а именно - 523,6 г и 534,0 г соответственно. 
Плодоводство и виноградарство Юга России № 58(04), 2019 г.

Bbыводы. Таким образом, по итогам многолетних исследований в условиях РСО-Алания выделены крупноплодные сорта яблони: летний Союз; осенние: Василиса, Кармен, Любава, Талисман, раннезимний Лигол; зимние и позднезимние: Любимое Дутовой, Золотая корона, 12/2-20-35, Прикубанское.

Среди выделенных нами по ценному для селекции признаку крупноплодности - все сорта яблони региональной селекции (исключение сорт Лигол). Большинство из выделенных сортов и элитных форм региональной селекции имеют иммунитет к парше: Союз, Василиса, Кармен, Любава, Талисман и 12/2-20-35. Наиболее крупноплодный среди всех изученных нами сортов яблони - осенний сорт Талисман, обладающий средней и максимальной массой плодов более 500 г. Среди летних сортов выявлен как наиболее крупноплодный в условиях республики Северная Осетия-Алания триплоидный сорт Союз.

Выделенные в ходе исследований сорта, и элитная форма яблони являются ценными источниками крупноплодности и могут быть рекомендованы для включения в различные селекционные программы, особенно при использовании метода межвидовой гибридизации для преодоления мелкоплодности, которой нередко обладают видовые и межвидовые формы с комплексом других селекционно значимых признаков.

\section{Литература}

1. Программа и методика селекции плодовых, ягодных и орехоплодных культур. Орел, 1995. 503 с.

2. Программа и методика сортоизучения плодовых, ягодных и орехоплодных культур. Орел, 1999. 606 с.

3. Современные методологические аспекты организации селекционного процесса в садоводстве и виноградарстве. Краснодар: СКЗНИИСиВ, 2012. 569 с.

4. Программа Северо-Кавказского центра по селекции плодовых, ягодных, цветочно-декоративных культур и винограда на период до 2030 года. Краснодар: СКЗНИИСиВ, 2013. 202 с.

5. Fischer C., Schreiber H., Buttner R., Fischer M. Testing scab-resistance stability of new resistant cultivars within the apple breeding program / Acta Horticulturae. - 1999. V. 484. - P. 449-454.

6. Janick J. History of the PRI apple breeding program / Acta Horticulturae. - 2002. V. 595. - P. 55-60. 
7. Durel C.E. Genetic dissection of partial resistance to rase 6 of Venturia inaequalis in apple // Durel C.E., Parisi L., Laurens F., Van de Weg W.E., Leirbherd R., Jourjon V.F. / Genome. - 2003. - V. 46(2). - P. 224-234.

8. Afunian M.R. Linkage Vfa4 in Malus $x$ domestica and Malus floribunda with $V f$ resistanse to the apple scab pathogen Venturia inaequalis / Afunian M.R., Goodwin P.H., Hunter D.M. // Plant Pathology. - 2004. - V. 53. - P. 461-467.

9. Седов Е.Н., Седышева Г.А., Серова 3.М. Селекция яблони на полиплоидном уровне. Орел: ВНИИСПК, 2008. 367 с.

10. Создание новых полиплоидных сортов яблони с генетической устойчивостью к парше / Е.Н. Седов, Г.А. Седышева, 3.М. Серова, Е.В. Ульяновская. // Садоводство и виноградарство. 2009. №1. С.14-15.

11. Costa F., Peace C. P., Stella S. [et al.] QTL dynamics for fruit firmness and softening around an ethylene-dependent polygalacturonase gene in apple (Malus $\times$ domestica Borkh.) / J. Expt. Bot., - 2010. - № 61. - P. 3029-3039.

12. Bus V.G.M. Revision of the nomenclature of the differential host-pathogen interactions of Venturia inaequalis and Malus / Annual Review of Phytopathology. - 2011. V. 49. - P. 391-413.

13. Комплексная оценка исходного материала яблони для селекции сортов нового поколения / А.Х. Пшеноков, А.С. Шидакова, Р.Ш. Заремук, И.И. Супрун // Политематический сетевой электронный научный журнал Кубанского государственного аграрного университета. 2013. № 93. С. 889-898.

14. Sedov E., Sedysheva G., Serova Z., Ulyanovskaya E. Creation of triploid grades opens a new era in apple-tree selection / Russian Journal of Horticulture, 2014. - T.1. - № 1. - C. $17-24$.

15. Изучение генетического разнообразия современных сортов яблони (Malus domestica) отечественной селекции с использованием микросателлитных локусов / И.И. Супрун, Я.В. Ушакова, С.В. Токмаков, Ч.Э. Дюрель, К. Денанс, Е.В. Ульяновская // Сельскохозяйственная биология. 2015. Т. 50. № 1. С. 37-45.

16. Савельева Н.Н. Биологические и генетические особенности яблони и селекция иммунных к парше и колонновидных сортов. Мичуринск-наукоград РФ, 2016. $280 \mathrm{c}$.

17. Ускоренное создание иммунных к парше сортов яблони с использованием молекулярно-генетических методов исследования / Е.В. Ульяновская, И.И. Супрун, Е.Н. Седов, Г.А. Седышева, 3.М. Серова. Краснодар, 2011. 55 с.

18. Fischer C., Richter K. Results on fire blight resistance breeding of the Pillnits apple breeding programme / Erwerbsobstbauu, 1999. - V. 41(2). - P. 56-60.

19. Keulemans, J. Genetic Diversity, Ploudy and Apomixis in Putative Qbince (Cydonia oblonga) x Apple (Malus domestica) Hybrids/ 28th Internat. Hort. Congr. - Lisbon, 2010. - V. 1. - P. 202.

20. Седов Е.Н. Селекция и новые сорта яблони. Орел: ВНИИСПК, 2011. 624 с.

21. Комплексная программа по селекции семечковых культур в России на 2001-2020 гг. Орёл, 2001. 29 с.

\section{References}

1. Programma i metodika selekcii plodovyh, yagodnyh i orekhoplodnyh kul'tur. Orel, 1995. $503 \mathrm{~s}$.

2. Programma i metodika sortoizucheniya plodovyh, yagodnyh i orekhoplodnyh kul'tur. Orel, 1999. $606 \mathrm{~s}$.

3. Sovremennye metodologicheskie aspekty organizacii selekcionnogo processa v sadovodstve i vinogradarstve. Krasnodar: SKZNIISiV, 2012. 569 s. 
4. Programma Severo-Kavkazskogo centra po selekcii plodovyh, yagodnyh, cvetochno-dekorativnyh kul'tur i vinograda na period do 2030 goda. Krasnodar: SKZNIISiV, 2013. $202 \mathrm{~s}$.

5. Fischer C., Schreiber H., Buttner R., Fischer M. Testing scab-resistance stability of new resistant cultivars within the apple breeding program / Acta Horticulturae. - 1999. V. 484. - P. 449-454.

6. Janick J. History of the PRI apple breeding program / Acta Horticulturae. - 2002. V. 595. - P. 55-60.

7. Durel C.E. Genetic dissection of partial resistance to rase 6 of Venturia inaequalis in apple // Durel C.E., Parisi L., Laurens F., Van de Weg W.E., Leirbherd R., Jourjon V.F. / Genome. - 2003. - V. 46(2). - P. 224-234.

8. Afunian M.R. Linkage Vfa4 in Malus x domestica and Malus floribunda with $V f$ resistanse to the apple scab pathogen Venturia inaequalis / Afunian M.R., Goodwin P.H., Hunter D.M. // Plant Pathology. - 2004. - V. 53. - P. 461-467.

9. Sedov E.N., Sedysheva G.A., Serova Z.M. Selekciya yabloni na poliploidnom urovne. Orel: VNIISPK, 2008. 367 s.

10. Sozdanie novyh poliploidnyh sortov yabloni s geneticheskoj ustojchivost'yu k parshe / E.N. Sedov, G.A. Sedysheva, Z.M. Serova, E.V. Ul'yanovskaya. // Sadovodstvo i vinogradarstvo. 2009. №1. S.14-15.

11. Costa F., Peace C. P., Stella S. [et al.] QTL dynamics for fruit firmness and softening around an ethylene-dependent polygalacturonase gene in apple (Malus $\times$ domestica Borkh.) / J. Expt. Bot., - 2010. - № 61. - R. 3029-3039.

12. Bus V.G.M. Revision of the nomenclature of the differential host-pathogen interactions of Venturia inaequalis and Malus / Annual Review of Phytopathology. - 2011. V. 49. - P. 391-413.

13. Kompleksnaya ocenka iskhodnogo materiala yabloni dlya selekcii sortov novogo pokoleniya / A.H. Pshenokov, A.S. Shidakova, R.Sh. Zaremuk, I.I. Suprun // Politematicheskij setevoj elektronnyj nauchnyj zhurnal Kubanskogo gosudarstvennogo agrarnogo universiteta. 2013. № 93. S. 889-898.

14. Sedov E., Sedysheva G., Serova Z., Ulyanovskaya E. Creation of triploid grades opens a new era in apple-tree selection / Russian Journal of Horticulture, 2014. - T.1. - № 1. - S. 17-24.

15. Izuchenie geneticheskogo raznoobraziya sovremennyh sortov yabloni (Malus domestica) otechestvennoj selekcii s ispol'zovaniem mikrosatellitnyh lokusov / I.I. Suprun, Ya.V. Ushakova, S.V. Tokmakov, Ch.E. Dyurel', K. Denans, E.V. Ul'yanovskaya // Sel'skohozyajstvennaya biologiya. 2015. T. 50. № 1. S. 37-45.

16. Savel'eva N.N. Biologicheskie i geneticheskie osobennosti yabloni i selekciya immunnyh k parshe i kolonnovidnyh sortov. Michurinsk-naukograd RF, 2016. $280 \mathrm{~s}$.

17. Uskorennoe sozdanie immunnyh $\mathrm{k}$ parshe sortov yabloni $\mathrm{s}$ ispol'zovaniem molekulyarno-geneticheskih metodov issledovaniya / E.V. Ul'yanovskaya, I.I. Suprun, E.N. Sedov, G.A. Sedysheva, Z.M. Serova. Krasnodar, 2011. 55 s.

18. Fischer C., Richter K. Results on fire blight resistance breeding of the Pillnits apple breeding programme / Erwerbsobstbauu, 1999. - V. 41(2). - P. 56-60.

19. Keulemans, J. Genetic Diversity, Ploudy and Apomixis in Putative Qbince (Cydonia oblonga) x Apple (Malus domestica) Hybrids/ 28th Internat. Hort. Congr. - Lisbon, 2010. - V. 1. - P. 202.

20. Sedov E.N. Selekciya i novye sorta yabloni. Orel: VNIISPK, 2011. 624 s.

21. Kompleksnaya programma po selekcii semechkovyh kul'tur v Rossii na 2001-2020 gg. Oryol, 2001. 29 s. 